\title{
Effects of Hot, Humid Weather on Milk Temperature, Dry Matter Intake, and Milk Yield of Lactating Dairy Cows
}

\author{
J. W. West, ${ }^{\star}$ B. G. Mullinix, $†$ and J. K. Bernard* \\ *Animal \& Dairy Science Department and \\ †Statistical and Computer Services \\ University of Georgia \\ Coastal Plain Experiment Station \\ Tifton 31793-0748
}

\section{ABSTRACT}

Lactating cows were exposed to moderate and hot, humid weather to determine the effect of increasing ambient temperature, relative humidity, or temperature-humidity index (THI) on intake, milk yield, and milk temperature. Minimum and maximum temperatures averaged 17.9 and $29.5^{\circ} \mathrm{C}$ (cool period) and 22.5 and $34.4^{\circ} \mathrm{C}$ (hot period), and minimum and maximum THI averaged 63.8 and 76.6 (cool period) and 72.1 and 83.6 (hot period). Environmental conditions had minor effects on intake and milk yield during the cool period. During the hot period, the THI $2 \mathrm{~d}$ earlier and mean air temperature $2 \mathrm{~d}$ earlier had the greatest impact on milk yield and DMI, respectively. Both breeds maintained milk temperature within normal ranges during the cool period, but Holstein and Jersey p.m. milk temperatures averaged 39.6 and $39.2^{\circ} \mathrm{C}$ during the hot period. Current day mean air temperature during the hot period had the greatest impact on cow p.m. milk temperature, and minimum air temperature had the greatest influence on a.m. milk temperature. Dry matter intake and milk yield declined linearly with respective increases in air temperature or THI during the hot period and milk temperature increased linearly with increasing air temperature. Dry matter intake and milk yield both exhibited a curvilinear relationship with milk temperature. Environmental modifications should target the effects of high temperatures on cow body temperature and should modify the environment at critical times during the day when cows are stressed, including morning hours when ambient temperatures are typically cooler and cows are not assumed to be stressed.

(Key words: lactation, intake, heat stress, milk temperature)

Received July 3, 2001.

Accepted January 29, 2002

Corresponding author: J. W. West; e-mail: jwest@tifton.uga. edu.

\begin{abstract}
Abbreviation key: $\mathbf{C O O L}=$ cool period, $\mathbf{H O T}=$ hot period, $\mathbf{R H}=$ relative humidity, $\mathbf{T H I}=$ temperaturehumidity index.
\end{abstract}

\section{INTRODUCTION}

Lactating dairy cows exposed to high ambient temperature, often coupled with high relative humidity (RH) or radiant energy (direct sunlight) usually respond with reduced milk yield. In Israel, the rectal temperature of cows increased during the day as ambient temperature increased to its maximum; milk yield declined with heat stress, but the effect was alleviated when cows were cooled (Her et al., 1988). Early Missouri work (Johnson et al., 1963) showed that cows consumed less feed as ambient temperature and combined ambient temperature and $\mathrm{RH}$ were increased, and that cows exposed to high ambient temperatures and low $\mathrm{RH}$ had greater intake than cows exposed to similar ambient temperatures but with high $\mathrm{RH}$. In addition, they reported that milk yield and TDN intake declined as rectal temperature increased (Johnson et al., 1963). Performance of cows is diminished by hot weather, and effects appear to be mediated through elevated body temperature.

The major challenge for high producing dairy cows in hot climates is to dissipate heat produced by metabolic processes. Metabolic heat production increases as the productive capacity of dairy cows improves. Cows yielding 18.5 and $31.6 \mathrm{~kg} / \mathrm{d}$ of milk produced 27.3 and $48.5 \%$ more heat, respectively, than dry cows (Purwanto et al., 1990). Cows in hot climates generally produce additional heat relative to cool climates because of the greater physical activity (such as panting) necessary to enhance cooling in hot conditions. Heat production for beef cattle exposed to $35^{\circ} \mathrm{C}$ ambient temperature was $141.8 \mathrm{kcal} / \mathrm{kg}$ of BW ${ }^{0.75}$, but was $124.5 \mathrm{kcal} / \mathrm{kg}$ of $\mathrm{BW}^{0.75}$ for those in thermoneutral conditions $\left(20^{\circ} \mathrm{C}\right.$ ) (Robinson et al., 1986). Cows administered bST under hot conditions produced about 25\% more heat than cows not receiving bST (Manalu et al., 1991). The greater heat production was associated with an approximate $49 \%$ 
increase in milk energy secretion, and increased heat production was balanced with greater heat dissipation. It is apparent that continued improvements in genetics and management techniques will continue to improve feed intake and milk yield for the dairy cow, contributing to greater metabolic heat production.

Environmental temperature, radiant energy, relative humidity, and wind speed contribute to the degree of heat stress or cooling that occurs for the cow. Temperature-humidity index (THI) incorporates the effects of both ambient temperature and $\mathrm{RH}$ in an index (NOAA, 1976). Classical work at Missouri (Kibler and Brody, 1953) demonstrated that as ambient temperature increased in the presence of low or high $\mathrm{RH}$, cooling mechanisms employed by the cow shifted from nonevaporative processes (convective, conductive, and radiation) to evaporative (sweating and panting). Combined effects of environmental stressors may be more critical to cow comfort and performance than single measures such as ambient temperature. Holter et al. (1996) reported that minimum THI was more closely correlated with DMI than maximum THI, and DMI depressions commenced when minimum THI was in the range of 56 to 59 and maximum THI was in the range of 71 to 73. Holstein DMI was closely correlated with minimum and maximum THI ( -0.63 and -0.62 , respectively), and multiparous cows were more drastically affected than primiparous cows (Holter et al., 1997). The correlation coefficient for a stepwise regression analysis in which summation of THI hours above 74 for the preceding 4 $\mathrm{d}$ was related to milk yield was reported to be 0.42 in South Carolina (Linvill and Pardue, 1992).

Improved description of the effects of environmental conditions on milk yield, DMI, and body temperature are needed to better predict the effects of seasonal heat stress. An understanding of the interaction of various environmental factors with lactational performance is necessary so that management techniques and cooling practices can be developed to meet the needs of the high producing cow subject to the effects of hot, humid conditions.

The objectives of this study were to determine the influence of environmental conditions on milk temperature, DMI, and milk yield and to determine the combined effects of environmental stressors (including ambient temperature, $\mathrm{RH}$, and the effects of previous days of exposure) on performance of lactating dairy cows exposed to hot, humid weather conditions.

\section{MATERIALS AND METHODS}

\section{Management of Cows}

Twenty-four Holstein and eight Jersey cows (all multiparous) averaging 60 DIM were selected for the study.
Data for two Holsteins that did not complete the experimental period due to injury or off-feed condition were omitted from the dataset, leaving 22 Holstein cows. Cows were housed in free-stall sheds, which had metal roofs over the free stalls and over the feeding area, but were open over the concrete flush alley between roofs. Cows had no supplemental cooling from fans or misters. Cows were fed TMR to achieve an approximate 10\% daily feed refusal using electronic feed doors and a mobile feed mixer mounted on electronic weigh cells (American Calan, Inc., Northwood, NH). Feeding and management are described in detail by West et al. (1999).

\section{Trial Schedule}

The study was conducted beginning April 28 and continuing through July 27. Weather conditions during this time of the year typically range from relatively cool in April to very hot and humid in June and July. Environmental conditions during the study are illustrated in Figure 1. Temperatures gradually increased during the trial, and cow performance exhibited a distinct change centered on June 2 . The period before June 2 is designated as the cool period (COOL), and the period from June 2 through July 27 is designated as the hot period (HOT).

\section{Data Collection}

Individual feed intake was measured daily. Samples of feeds and TMR were collected weekly and dried at $60^{\circ} \mathrm{C}$ for $72 \mathrm{~h}$. The DM percentages of feed ingredients were used to adjust ration components each week, and DM percentages of TMR were used to calculate daily DMI. Milk yield was measured at each milking (twice daily) using calibrated weigh jars. In addition, milk temperature was measured using a thermocouple in the short milk tube of each milker (Temp-Sense; Udder Health Systems, Bellingham, WA). Milk temperature was used as an indicator of cow body temperature and was collected by the sensor in the short milk tube immediately upon leaving the teat. In a study in which thermistor probes were implanted in the secretary tissue of the udder and in the peritoneal cavity, udder temperature was highly correlated with peritoneal temperature (Bitman et al., 1982). Igono et al. (1987) reported that p.m. milk temperature and rectal temperature had a correlation of 0.87 for shaded cows, and 0.89 for cows in shade, spray and fans. Using the milk temperature system described here, West et al. (1990) reported a correlation of milk and rectal temperature of 0.89. In the nutritional study conducted concurrently with the present work, West et al. (1999) reported a 0.78 correla- 


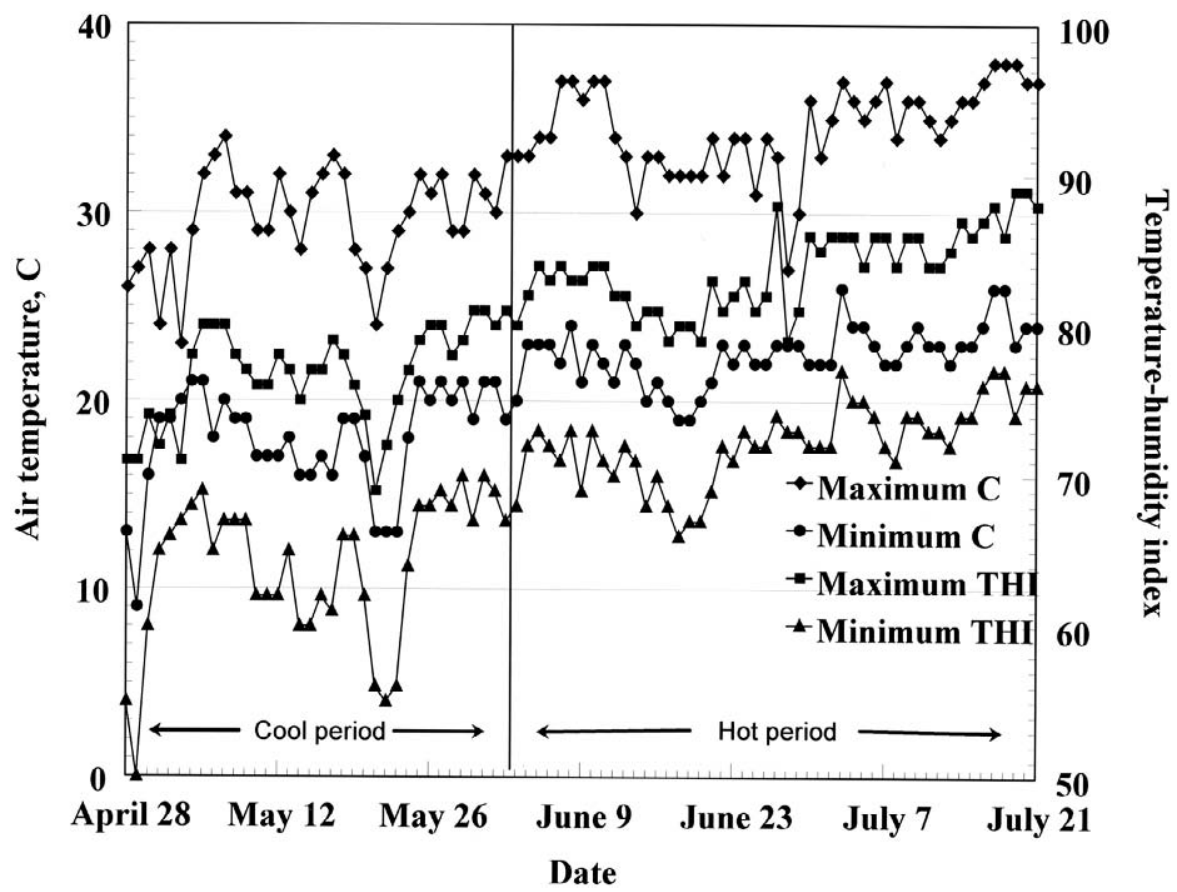

Figure 1. Maximum and minimum temperature $\left({ }^{\circ} \mathrm{C}\right)$ and temperature-humidity index (THI) during the study.

tion $(P>0.001)$ of milk and rectal temperatures, and milk temperatures averaged $0.15^{\circ} \mathrm{C}$ higher than rectal temperature. Thus milk temperature is a good indicator of body temperature, and Hetzel (1988) stated that rectal temperature is prone to error from sources such as variability in depth and duration of probe insertion, as well as variation in animal handing. Thus, milk temperature is a superior and less variable measure of the deep body temperature of the cow than is rectal temperature due to the high degree of vascularity of the mammary gland.

Ambient temperature and $\mathrm{RH}$ were monitored continuously in the feeding area (immediately adjacent to the free stalls) with a hygrothermograph (Omega Engineering, Inc., Stamford, CT) with an accuracy of \pm $1^{\circ} \mathrm{C}$, and $\pm 3 \% \mathrm{RH}$. Maximum and minimum ambient temperature and $\mathrm{RH}$ were determined for each 24-h period and were used to calculate THI (NOAA, 1976). The equation used for THI was: $\mathrm{THI}=\mathrm{td}-(0.55-0.55$ $\mathrm{RH})(\mathrm{td}-58)$, where $\mathrm{td}$ is the dry bulb temperature in ${ }^{\circ} \mathrm{F}$ and $\mathrm{RH}$ is relative humidity expressed as a decimal (NOAA, 1976). For each 24 -h period, maximum THI was calculated using maximum temperature and minimum $\mathrm{RH}$, and minimum THI was calculated using minimum temperature and maximum $\mathrm{RH}$.

\section{Statistical Analyses}

The data for the current study were collected in conjunction with a nutritional study (West et al., 1999).
Preliminary analyses using Proc MIXED (SAS, 1999) revealed that the relationship between milk production and the environmental data removed (or explained) a part of the treatment differences. Inclusion of DMI as a covariate removed the balance of the treatment differences. Taken alone, DMI removed a significant portion of the treatment differences. Thus it was concluded that with either environmental data and/or DMI in the model, data could be pooled across treatments.

To determine the point at which performance diverged and the end of COOL and the beginning of HOT periods occurred, the data were divided into two groups for selecting a day when the cow milk temperature relationship changed significantly. The relationship between Julian day and cow milk temperature was determined within each group. The boundary day was moved until the relationship was nonsignificant before this day, and was significant from this day forward. The day when this occurred was June 2 . Thus the period before June 2 was designated as the COOL period, while from June 2 forward was designated as the HOT period. Proc GLM (SAS, 1999) was used in this determination.

Means for milk temperatures were compared for breed differences using unequal variance $t$ test (Steele and Torrie, 1960). Correlations among the cow data (milk production, DMI, milk temperature) and the environmental data were performed using Proc CORR (SAS, 1999). Regression coefficients were determined using Proc MIXED (SAS, 1999) for those correlations that 
were found to be highly significant $(P>0.0001)$. For missing milk yield, DMI, and a.m. and p.m. milk temperature data, the best linear or quadratic relationship was determined between the variable and Julian day for each cow. Predicted values were obtained and used to fill in the missing data. For all regressions, the y values were unique values that occurred in the dataset, regardless of the number of data points that made up that unique value. Thus, for each unique value, a mean was determined for the dependent variable (Draper and Smith, 1981). There was no missing environmental data since there were three automated recording stations operating near the research site to supplement the collection of on-site data.

Forward stepwise regression (SAS, 1999) was used to identify environmental variables that influenced milk yield, DMI, and a.m. and p.m. milk temperatures for Holstein and Jersey cows during COOL and HOT. Climatic variables included for selection by stepwise regression were daily minimum, maximum, and mean for ambient temperature, $\mathrm{RH}$, and THI. The a.m. and p.m. milk temperatures were included for selection in the stepwise regression for DMI and milk yield as dependent variables. In addition to considering the current day effects of these variables, the effects of the measures 1,2 , and $3 \mathrm{~d}$ before the measurement of the dependent variable were determined. These effects were termed the lag effects, which consider the environmental effects that occurred 1,2 , or $3 \mathrm{~d}$ before the day in which milk yield, DMI, and milk temperature were measured. Thus the 2-d lag effect would be the effect of that environmental variable measured $2 \mathrm{~d}$ previously on current day performance (DMI, milk yield, or milk temperature). For variables to be considered by the forward stepwise regression, a partial correlation coefficient of 0.3 must have occurred, and a significance of 0.05 was required for the variable to remain in the model.

\section{RESULTS AND DISCUSSION}

\section{Environmental Conditions}

Weather conditions in southern Georgia typically range from warm to very hot and humid during the time when this work was conducted. Average weather conditions are presented in Table 1 . Note that mean air temperature was approximately $5^{\circ} \mathrm{C}$ warmer during HOT compared with COOL, while mean $\mathrm{RH}$ was 4 percentage points higher and mean THI was 7.7 units higher during HOT. Mean THI was 77.9 during HOT and 70.2 during COOL. A mean daily THI of 72 is considered the critical point at which milk yield is reduced (Johnson, 1987). Increasing THI in the range of 71 to 81 reduced the milk yield and intake of TDN and water for dairy cows (Johnson et al., 1963), and the effect was greatest when THI exceeded 76 . Note that during HOT, maximum THI averaged 83.6 and the average minimum exceeded the critical point of 72 . Therefore, on average, cows were continuously exposed to stressful conditions throughout the HOT period.

A distinct change in weather conditions was noted around June 2 (Figure 1). During COOL, the daily ambient temperature and THI showed a gradual increasing trend over time, but on and following June 2 (HOT) higher ambient temperature and THI were observed than during COOL and temperature and THI were more stable (less day-to-day variation) and elevated than during COOL. Standard deviations for temperature and THI were less during HOT than during COOL (Table 1), indicating less variation in heating and cooling and more consistent and chronic heat during the HOT period. Reduced daily fluctuation in temperature and THI during HOT is evident in Figure 1. Note in Figure 1 that during much of HOT, the minimum THI was at or above 72 and the maximum THI was well above 76 so that the mean THI easily exceeded the critical point of 72, suggesting that cows were exposed continuously to conditions conducive to heat stress. Igono et al. (1992) reported that during heat stress the hours per day with temperatures less than $21^{\circ} \mathrm{C}$ provided a margin of safety to reduce the effects of heat stress on production. They reported that the critical minimum, mean, and maximum temperatures and THI for milk production are 21,27 , and $32^{\circ} \mathrm{C}$ and 64,72 , and 76 , respectively. It is clear that environmental conditions in the present study were sufficiently hot to induce heat stress.

\section{Cow Milk Temperature}

Cow milk temperature (Table 2) was elevated during HOT. Normal temperature for cows in a thermoneutral environment is near $38.6^{\circ} \mathrm{C}$. Neither Holstein or Jersey cows achieved normal milk temperatures at either the a.m. or p.m. milkings during HOT, an indication that cows were subjected to continual heat stress, while cows maintained near normal milk temperatures during COOL. The elevated milk temperature observed during HOT is consistent with the mean THI that exceeded the critical point of 72 . Cows subjected to thermoneutral $\left(18^{\circ} \mathrm{C}, 60 \% \mathrm{RH}\right)$ and hot $\left(32^{\circ} \mathrm{C}, 50 \% \mathrm{RH}\right)$ conditions in climatic chambers exhibited sharp increases in rectal temperature when exposed to the hot environment (Johnson et al., 1988), and increases were greatest for early lactation cows at high production compared with lower yielding mid- and late-lactation cows. The elevated rectal temperatures were associated with concomitant reductions in DMI and milk yield. Milk production declined when rectal temperature exceeded 
Table 1. Mean weather conditions during the study.

\begin{tabular}{lllrllll}
\hline Variable & Period & Minimum & SD & Maximum & SD & Mean & SD \\
\hline Temperature, ${ }^{\circ} \mathrm{C}$ & Cool & 17.9 & 2.8 & 29.5 & 2.6 & 23.7 & 2.3 \\
& Hot & 22.5 & 1.6 & 34.4 & 2.2 & 28.5 & 1.7 \\
Relative humidity, \% & Cool & 42.3 & 10.5 & 92.0 & 5.7 & 67.2 & 6.3 \\
& Hot & 46.1 & 9.3 & 96.2 & 4.7 & 71.2 & 6.1 \\
THI $^{1}$ & Cool & 63.8 & 4.9 & 76.6 & 3.2 & 70.2 & 3.7 \\
& Hot & 72.1 & 2.7 & 83.6 & 2.7 & 77.9 & 2.5 \\
\hline
\end{tabular}

\footnotetext{
${ }^{1}$ Temperature-humidity index. $\mathrm{THI}=\mathrm{td}-(0.55-0.55 \mathrm{RH})(\mathrm{td}-58)$, where $\mathrm{td}$ is dry bulb temperature
} $\left({ }^{\circ} \mathrm{F}\right)$ and $\mathrm{RH}$ is relative humidity, presented as a decimal.

$39^{\circ} \mathrm{C}$ for more than $16 \mathrm{~h}$ (Igono and Johnson, 1990). Cows in the present study exceeded $39^{\circ} \mathrm{C}$ at both the a.m. and p.m. milkings, when cow temperatures should have been near their lowest and highest points, respectively. Given the consistently elevated milk temperature during HOT, a significant decline in milk yield is predicted.

\section{Environmental Factors Influencing Performance}

COOL period. Table 3 contains results of stepwise regression analysis during the COOL period. Climatic variables that had statistically significant effects on milk yield and DMI during COOL were selected. The first climatic variable selected for milk yield for both breeds was the p.m. cow milk temperature (Table 3). The variable with the greatest influence on DMI was daily mean milk temperature for Holsteins and p.m. milk temperature for Jerseys (Table 3), although $R^{2}$ were very low and the actual effect on performance would be expected to be minimal. The $\mathrm{R}^{2}$ for climate and milk temperature variable selected for the COOL period had relatively weak relationships with performance variables, and in all cases explained $28 \%$ or less of the total variation (Table 3). This illustrates that climatic conditions had a relatively small effect on performance during COOL.
Near the end of COOL, ambient temperature was increasing and cows may have experienced some warming, supported by the higher $\mathrm{R}^{2}$ for environmental variables associated with cow a.m. and p.m. milk temperatures (Table 3 ). The variable with the greatest influence on a.m. milk temperature during COOL was mean THI for Holsteins and minimum THI for Jerseys, while mean air temperature was the first variable selected for p.m. milk temperature for both breeds. The $R^{2}$ for environmental variables influencing cow milk temperatures were larger than those for DMI and milk yield, indicating that environmental conditions had a greater effect on milk temperature than on DMI or milk yield. Changes in milk yield and DMI were minimal, indicating that cows were able to maintain body temperature within a range that enabled them to maintain performance. Cow milk temperatures remained near normal during COOL (Table 2), and weather conditions were moderate and cow performance was not impacted.

Climatic chamber work showed that altering $\mathrm{RH}$ within a temperature range of -11 to $4^{\circ} \mathrm{C}$ had no consistent effect on heat production, evaporative cooling via the respiratory tract, or on rectal temperature or respiratory rate (Kibler and Brody, 1953). However, raising the $\mathrm{RH}$ within a temperature range of 24 to $38^{\circ} \mathrm{C}$ increased rectal temperature and respiratory rate in dairy cows. The authors observed that one reason $\mathrm{RH}$

Table 2. Cow milk temperatures during the study. ${ }^{1}$

\begin{tabular}{|c|c|c|c|c|c|c|c|c|}
\hline \multirow[b]{2}{*}{ Breed } & \multirow[b]{2}{*}{ Period } & \multirow{2}{*}{$\begin{array}{l}\text { Number of } \\
\text { observations }\end{array}$} & \multicolumn{4}{|c|}{ Milking time } & \multirow[b]{2}{*}{ Mean } & \multirow[b]{2}{*}{ SE } \\
\hline & & & a.m. & SE & p.m. & SE & & \\
\hline & & & & & Milk te & ature, & & \\
\hline \multirow[t]{2}{*}{ Holstein } & $\mathrm{Cool}^{2}$ & 792 & 38.8 & 0.01 & 38.9 & 0.02 & 38.9 & 0.02 \\
\hline & $\mathrm{Hot}^{3}$ & 1078 & 39.3 & 0.02 & 39.6 & 0.02 & 39.4 & 0.02 \\
\hline \multirow[t]{2}{*}{ Jersey } & $\mathrm{Cool}^{2}$ & 288 & 38.5 & 0.02 & 38.6 & 0.02 & 38.5 & 0.02 \\
\hline & $\mathrm{Hot}^{3}$ & 392 & 39.1 & 0.02 & 39.2 & 0.03 & 39.1 & 0.03 \\
\hline
\end{tabular}

\footnotetext{
${ }^{1}$ Unequal variance $t$ test was used to compare breeds within COOL and HOT periods (Steele and Torrie, 1960).

${ }^{2} \mathrm{COOL}$ period $\mathrm{t}$ value for Holsteins versus Jerseys at the a.m. milking $=13.18(P<0.01)$.

COOL period $t$ value for Holsteins versus Jerseys at the p.m. milking $=11.95(P<0.01)$.

${ }^{3} \mathrm{HOT}$ period $\mathrm{t}$ value for Holsteins versus Jerseys at the a.m. milking $=6.41(P<0.01)$.

HOT period $t$ value for Holsteins versus Jerseys at the p.m. milking $=11.27(P<0.01)$.
} 
Table 3. Selection by stepwise regression of the three most influential climatic variables affecting Holstein and Jersey performance during the cool period.

\begin{tabular}{|c|c|c|c|c|c|c|}
\hline \multirow[b]{2}{*}{ Item } & \multicolumn{3}{|c|}{ Holstein - COOL Period } & \multicolumn{3}{|c|}{ Jersey - COOL Period } \\
\hline & $\begin{array}{l}\text { Variables } \\
\text { in model }^{1}\end{array}$ & Climate variable & $\begin{array}{l}\mathrm{R}^{2} \text {, } \\
\text { Cumulative }^{2}\end{array}$ & $\begin{array}{l}\text { Variables } \\
\text { in model }^{1}\end{array}$ & Climate variable & $\begin{array}{l}\mathrm{R}^{2} \\
\text { Cumulative }\end{array}$ \\
\hline \multirow{2}{*}{ Milk } & 2 & $\begin{array}{l}\text { I-d lag } \\
\text { maximum } \mathrm{THI}^{3}\end{array}$ & 0.05 & 2 & $\begin{array}{l}\text { p.m. Maximum THI } \\
\text { 3-d lag }\end{array}$ & 0.11 \\
\hline & $5^{3}$ & Final model & 0.07 & $4^{4}$ & Final model & 0.16 \\
\hline \multirow[t]{2}{*}{ DMI } & 1 & $\begin{array}{l}\text { Mean milk } \\
\text { temperature } \\
\text { 1-d lag } \\
\text { maximum air }\end{array}$ & 0.02 & 1 & $\begin{array}{l}\text { p.m. milk } \\
\text { temperature } \\
1 \mathrm{~d} \text { lag } \\
\text { maximum air }\end{array}$ & 0.13 \\
\hline & 2 & $\begin{array}{l}\text { temperature } \\
3 \text {-d lag }\end{array}$ & 0.05 & 2 & temperature & 0.20 \\
\hline \multirow{2}{*}{$\begin{array}{l}\text { a.m milk } \\
\text { temperature }\end{array}$} & 2 & $\begin{array}{l}\text { temperature } \\
\text { 3-d lag }\end{array}$ & 0.18 & 2 & temperature & 0.19 \\
\hline & $\begin{array}{l}3 \\
6^{3}\end{array}$ & $\begin{array}{l}\text { maximum air } \\
\text { temperature } \\
\text { Final model }\end{array}$ & $\begin{array}{l}0.20 \\
0.22\end{array}$ & $2^{4}$ & Final model & 0.19 \\
\hline \multirow{4}{*}{$\begin{array}{l}\text { p.m milk } \\
\text { temperature }\end{array}$} & & Mean air & & & Mean air & \\
\hline & 1 & temperature & 0.24 & 1 & temperature & 0.21 \\
\hline & 2 & $\begin{array}{l}\text { THI } \\
\text { Maximum relative }\end{array}$ & 0.27 & 2 & THI & 0.22 \\
\hline & $\begin{array}{l}3 \\
3^{3}\end{array}$ & $\begin{array}{l}\text { humidity } \\
\text { Final model }\end{array}$ & $\begin{array}{l}0.28 \\
0.28\end{array}$ & $2^{4}$ & Final model & 0.22 \\
\hline
\end{tabular}

${ }^{1}$ Significant at $P<0.05$.

${ }^{2} \mathrm{R}^{2}$ values are cumulative and reflect the amount of variation described by adding the significant variables to the model.

${ }^{3} \mathrm{THI}=$ Temperature-humidity index.

${ }^{4}$ Number of significant variables in the final model.

is not a greatly influential factor at low temperatures is because air holds a very small quantity of water at low temperatures and a relatively large volume of water at high temperatures and thus impacts the ability of the animal to evaporate moisture to the environment. Ambient temperature during COOL, coupled with minimal impact of $\mathrm{RH}$, resulted in no effect on milk temperature of cows during the COOL period.

HOT period. The climatic variable found to have the greatest impact on milk yield was the $2 \mathrm{~d}$ lag of mean THI (both breeds; Table 4). Second variables selected were 3-d lag of mean THI (Holsteins) and 1-d lag of maximum air temperature (Jerseys). The first variables selected for DMI were 2-d lag of mean air temperature (both breeds). Second variable was a $3-d$ lag of mean THI (Holsteins) and a 3-d lag of maximum THI (Jerseys). These lag effects examine the effects of the ambient environment or the cow's body temperature on per- formance variables 1,2 , or 3 days before the day the performance variable is measured. Thus a significant 2-d lag effect of mean THI on milk yield implies that the effects of the mean THI $2 \mathrm{~d}$ earlier had a greater effect on milk yield than current day measures or 1 or $3 \mathrm{~d}$ lag effects. In all cases, the first variable selected had the greatest $R^{2}$, and variables selected subsequently did not improve $\mathrm{R}^{2}$ greatly.

The lags of previous-day environmental measures were selected first for milk yield and DMI, and sameday measures of climatic variables were largely ignored. Mean air temperature had the greatest influence on milk yield for Holstein cows fed high or low concentrate diets under hot conditions (Kabuga and Sarpong, 1991), but neither THI for the current day nor mean temperature for the previous day was found to have a significant effect. However, in South Carolina, the model that best described environmental effects on milk 
Table 4. Selection by stepwise regression of the three most influential climatic variables affecting Holstein and Jersey performance during the hot period.

\begin{tabular}{|c|c|c|c|c|c|c|}
\hline \multirow[b]{2}{*}{ Item } & \multicolumn{3}{|c|}{ Holstein - HOT Period } & \multicolumn{3}{|c|}{ Jersey - HOT Period } \\
\hline & $\begin{array}{l}\text { Variables } \\
\text { in model }^{1}\end{array}$ & Climate variable & $\begin{array}{l}\mathrm{R}^{2}, \\
\text { Cumulative }^{2}\end{array}$ & $\begin{array}{l}\text { Variables } \\
\text { in model }^{1}\end{array}$ & Climate variable & $\begin{array}{l}\mathrm{R}^{2} \text {, } \\
\text { Cumulative }^{2}\end{array}$ \\
\hline Milk & 2 & $\begin{array}{l}\text { 3-d lag mean } \\
\text { THI } \\
1-d \text { lag }\end{array}$ & 0.24 & 2 & $\begin{array}{l}\text { 1-d lag maximum air } \\
\text { temperature }\end{array}$ & 0.20 \\
\hline \multirow{4}{*}{ DMI } & $5^{4}$ & Final model & 0.25 & $5^{4}$ & Final model & 0.25 \\
\hline & 1 & $\begin{array}{l}\text { 2-d lag mean air } \\
\text { temperature } \\
3 \text {-d lag mean }\end{array}$ & 0.24 & 1 & $\begin{array}{l}\text { 2-d lag mean air } \\
\text { temperature } \\
3 \text {-d lag }\end{array}$ & 0.35 \\
\hline & 2 & $\begin{array}{l}\text { THI } \\
\text { 1-d lag mean air }\end{array}$ & 0.28 & 2 & $\begin{array}{l}\text { maximum THI } \\
\text { p.m. milk }\end{array}$ & 0.40 \\
\hline & 3 & temperature & 0.29 & 3 & temperature & 0.43 \\
\hline \multirow{2}{*}{$\begin{array}{l}\text { a.m milk } \\
\text { temperature }\end{array}$} & 3 & relative humidity & 0.19 & 3 & relative humidity & 0.17 \\
\hline & $10^{4}$ & Final model & 0.25 & $4^{4}$ & Final model & 0.18 \\
\hline \multirow{5}{*}{$\begin{array}{l}\text { p.m milk } \\
\text { temperature }\end{array}$} & & Mean air & & & Mean air & \\
\hline & 1 & temperature & 0.34 & 1 & temperture & 0.25 \\
\hline & 2 & $\begin{array}{l}\text { 3-d lag minimum } \\
\text { relative humidity } \\
\text { 1-d maximum }\end{array}$ & 0.35 & 2 & $\begin{array}{l}\text { Relative humidity } \\
\text { (nonsignificant) }\end{array}$ & 0.25 \\
\hline & & relative humidity & 0.36 & $1^{4}$ & Final model & 0.25 \\
\hline & $6^{3}$ & Final model & 0.38 & & & \\
\hline
\end{tabular}

${ }^{1}$ Significant at $P<0.05$.

${ }^{2} R^{2}$ values are cumulative and reflect the amount of variation described by adding the significant variables to the model.

${ }^{3} \mathrm{THI}=$ Temperature-humidity index.

${ }^{4}$ Number of significant variables in the final model.

yield included total hours during the past $4 \mathrm{~d}$ during which the THI was $<74$, and the square of total hours during the past day during which the THI was $<80$ (Linvill and Pardue, 1992). The correlation coefficient at the point that THI hours above 74 entered the equation was 0.42 , and when THI hours above 80 entered the equation the correlation coefficient was 0.43 (Linvill and Pardue, 1992). Having a lag of time before the full effects of an environmental event on milk yield and DMI are expressed is logical because of the time required for a cow to consume, digest, and metabolize nutrients. Intake is reduced in response to heat stress and elevated body temperature, and there is a delay before the effect on performance is fully expressed. However, highly negative correlations for milk yield and DMI with maximum and minimum THI using same-day measures have been shown for Holsteins (Holter et al., 1997) and for Jerseys (Holter et al., 1996).

Unlike DMI and milk yield, same-day climatic variables during HOT were selected as having the greatest effect on milk temperature of the cow (Table 4). Mini- mum air temperature had the greatest influence on a.m. milk temperature for both breeds, and mean air temperature had the greatest influence on p.m. milk temperature for both breeds. Igono et al. (1988) reported that milk temperature was elevated when the average daily THI was in the 61 to 70 range and was greatest when THI was 71 or greater. The minimum THI averaged 72.1 during HOT in the present study (Table 1) and one would expect body temperature to be elevated for cows exposed to that environment. Legates et al. (1991) reported that in field studies air temperature had the greatest impact on physiological measures, radiation was second in importance, followed by vapor pressure and air movement. In the present study, air temperature had the greatest impact on both a.m. and p.m. cow milk temperature, while different lags of $\mathrm{RH}$ had a minor effect. Increasing air temperature reduces the temperature differential between cow body temperature and the ambient temperature and decreases the transfer of heat to the environment. Classical work demonstrated that the percentage of cooling originating 
Table 5. Change in performance variable with one unit change in the climatic variable during HOT period.

\begin{tabular}{llrr}
\hline & & \multicolumn{2}{c}{ Unit change $^{1}$} \\
\cline { 3 - 4 } Performance variable change & Climatic variable & Holstein & Jersey \\
\hline Milk yield, kg/THI unit & 2-d lag mean THI ${ }^{2,3}$ & -0.88 & -0.60 \\
DMI, kg/ $/{ }^{\circ}$ & 2-d lag mean air temperature & -0.85 & -0.84 \\
a.m. milk temperature,${ }^{\circ} \mathrm{C} /{ }^{3} \mathrm{C}$ & Minimum air temperature & 0.12 & 0.12 \\
p.m. milk temperature ${ }^{\circ} \mathrm{C} /{ }^{\circ} \mathrm{C}$ & Mean air temperature & \\
Milk yield, kg/THI unit & Same day mean THI & \\
DMI, kg/THI unit & Same day mean $\mathrm{THI}^{4}$ & 0.20 & -0.45 \\
& & -0.69 & -0.47 \\
\hline
\end{tabular}

${ }^{1}$ Linear effect unless noted otherwise

${ }^{2}$ Temperature-humidity index

${ }^{3}$ First variable selected by stepwise regression

from nonevaporative processes declined as ambient temperature increased, while evaporative processes increased (Kibler and Brody, 1950). The RH had little apparent impact on milk temperature in the present study, while air temperature had the predominant effect. Perhaps because temperature and $\mathrm{RH}$ were both relatively high during HOT, ambient temperature exerted the greater influence.

Table 5 contains data comparing the unit change in a performance variable per unit change in climatic variables. Climatic variables for milk yield, DMI, and a.m. and p.m. milk temperatures were those chosen first by stepwise regression. In addition, data for same day THI effects on milk yield and DMI are presented. Note that the effect of same day measures of THI on milk yield and DMI are substantially less than the effects of THI and mean air temperature $2 \mathrm{~d}$ previously on milk yield and DMI. These data have important implications for intake and milk yield prediction equations that typically rely on same-day climatic measures to predict performance responses. In the present study, the effect of climatic measures $2 \mathrm{~d}$ before the measurement of DMI and milk yield that had the greater effect on performance, reflected by the greater unit changes displayed in Table 5.

Graphs depicting the relationship of DMI with 2-d lag of mean air temperature and milk yield with 2 -d lag of mean THI are presented in Figure 2. The independent variables used were those selected first by stepwise regression (Table 4). There was a linear decline in DMI with increasing 2-d lag of mean air temperature for both breeds (Figure 2a). The rate of decline was similar for both breeds across the range of temperature experienced. Milk yield declined for both breeds across the range of THI in the HOT period (Figure $2 \mathrm{~b}$ ). The decline in milk yield for the Holsteins was more rapid than for Jerseys across the range of THI. Cummins et al. (1992) reported that milk yield and DMI declined in a linear fashion across a temperature range of 10 to $28^{\circ} \mathrm{C}$. In Ghana, the mean temperature for the current day had a -0.69 correlation with milk yield and had a greater effect on milk yield than minimum or maximum temperature, the mean temperature for the previous day,
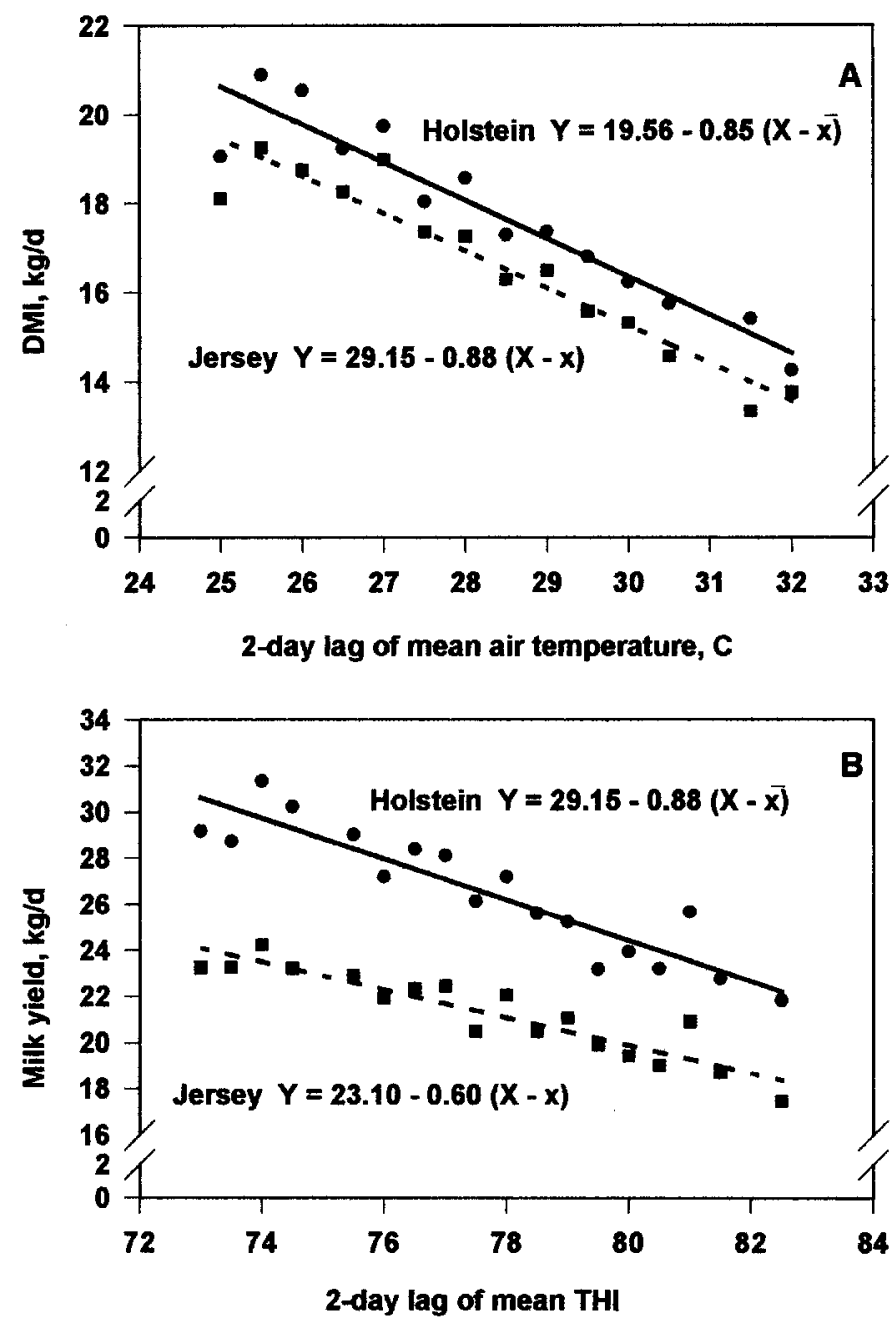

Figure 2. Regressions of DMI on 2-d lag of mean air temperature (A) and milk yield on 2-d lag of mean temperature humidity index (B) for Holstein $(\bullet)$ and Jersey (ロ) cows. 
or for the present-day THI (Kabuga and Sarpong, 1991). In Arizona, daily milk yield declined linearly with increasing ambient temperature and when regressed on minimum daily temperature or minimum THI had R values of 0.84 and 0.86 , respectively (Igono et al., 1992).

The reason for selection of the 2-d lag of air temperature for DMI effects versus the 2-d lag of THI for milk is unknown. However, temperature and THI are closely related and the effects are difficult to separate. The key relationship may be the effects of environment on milk temperature. The first variable selected for a.m. and p.m. milk temperatures during HOT were minimum and mean air temperatures (Table 4), again emphasizing ambient temperature over THI. Cow p.m. milk temperature increased linearly with increasing mean air temperature for the current day for both breeds (Figure 3a). Similarly, minimum current day air temperature had the greatest effect on a.m. milk temperature, and a.m. milk temperature increased linearly for both breeds (Figure 3b). Others have reported elevated rectal temperature with increasing ambient temperature (Igono and Johnson, 1990), and Maust et al. (1972) reported that the mean daily ambient temperature was more highly correlated with p.m. rectal temperature than 2-d mean or daily maximum or minimum temperature. Jerseys tended to be cooler at all environmental temperatures compared with Holsteins (Table 2, Figure 3). Across an ambient temperature range of 27 to $38^{\circ} \mathrm{C}$, body temperature for Holstein controls increased at a rate similar to Jersey controls, but Holsteins maintained an approximately $0.3^{\circ} \mathrm{C}$ greater body temperature than Jerseys across the temperature range (West et al., 1990). When the cows were administered bST, both breeds increased body temperature at a similar rate across the environmental temperature range, but there was no difference in body temperature among breeds, perhaps due to greater milk yield associated with bST use (West et al., 1990).

The relationship of milk temperature with DMI and milk yield is illustrated in Figure 4. The relationships were curvilinear and Holsteins appeared to maintain both intake and milk yield until milk temperature reached approximately $39^{\circ} \mathrm{C}$, after which both DMI and milk yield decreased at an increasing rate. The shape of the curve suggests that Holsteins were able to maintain DMI and milk yield with a moderate increase in milk temperature but at a threshold near $39^{\circ} \mathrm{C}$ a decline in performance began. The Jersey DMI and milk yield responses were curvilinear and tended to decline at a lower milk temperature relative to Holsteins, and the decline was more gradually (Figure 4). Milk yield was highly correlated with cow p.m. rectal temperature $3 \mathrm{~d}$ previously but not for the same day (Maust et al., 1972). Response for feed intake was similar, and correlations
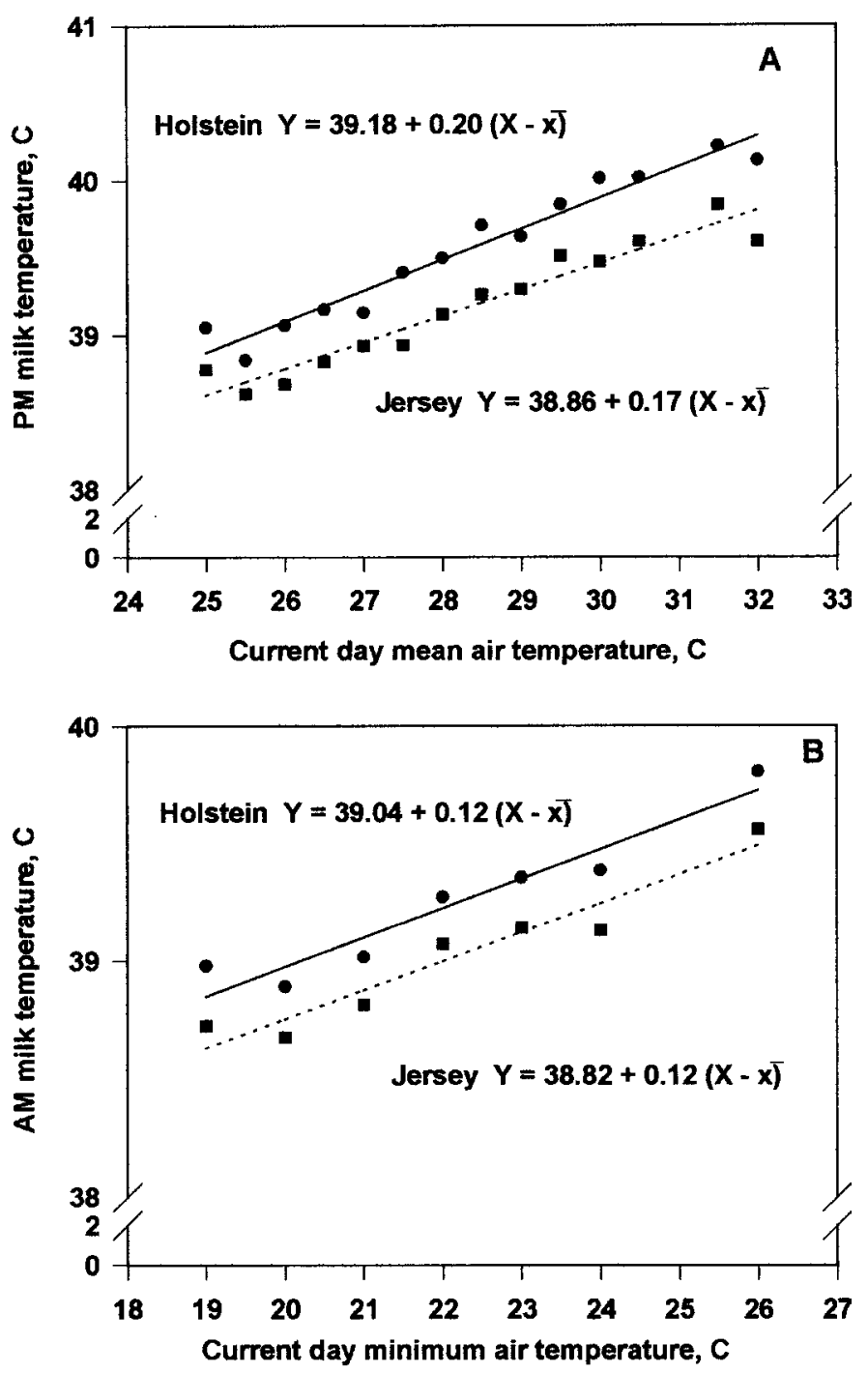

Figure 3. Regressions of p.m. milk temperature on current day mean air temperature (A) and a.m. milk temperature on current day minimum air temperature (B) for Holstein (-) and Jersey (ם).

were greater for midlactation cows compared with early- or late-lactation cows (Maust et al., 1972). Cows in midlactation typically have greater DMI compared with early- or late-lactation cows and rely less on body stores for milk yield compared with early-lactation cows. Cows consuming larger volumes of feed typically generate more heat. Jersey milk temperature tended to be lower than for Holsteins (Figure 3).

\section{CONCLUSIONS}

During heat stress, the effect of mean THI $2 \mathrm{~d}$ earlier had the greatest influence on milk yield, while the effect of mean ambient temperature $2 \mathrm{~d}$ earlier had the greatest effect on DMI. Current-day temperatures had the 


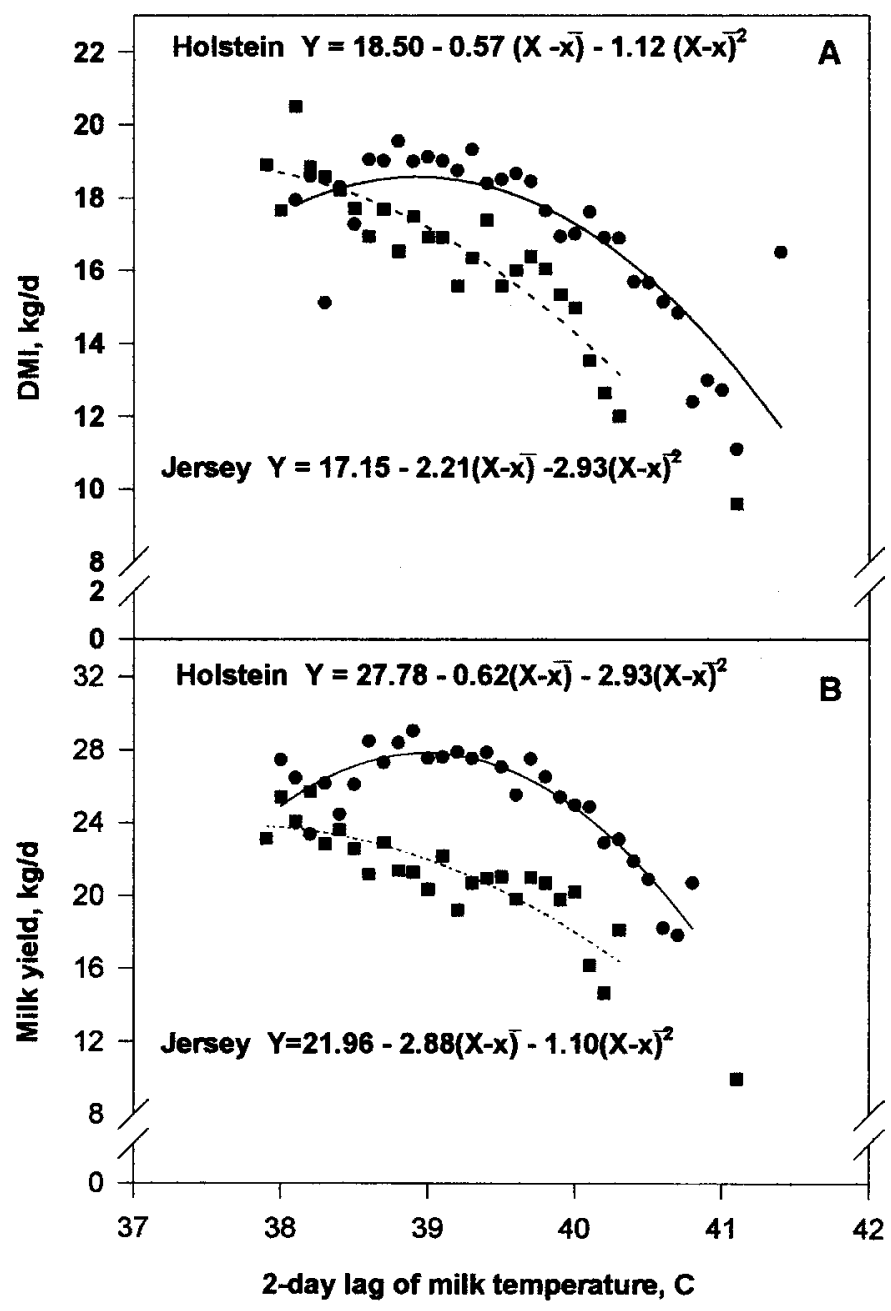

Figure 4. Regressions of DMI (A) and milk yield (B) on 2-d lag of milk temperature (B) for Holstein (@) and Jersey (ם) cows.

greatest impact on cow milk temperature. In many research trials, the impact of same day climatic events on performance are reported. However, results from the present study indicate that the effect of climatic factors before the current day may have a greater impact on milk yield and DMI.

Intake decline during hot weather was similar for both breeds. Milk (body) temperature increased at a similar rate for both breeds, but Jerseys consistently had a lower absolute milk temperature. The decline in performance associated with milk temperature was curvilinear for both breeds.

These data have implications for prediction equations that use same-day measures of environmental conditions to aid in predicting milk yield or DMI. Environmental measures $2 \mathrm{~d}$ before measurement of the performance variable had a greater impact and relationship with changes in cow performance in response to envi- ronmental changes and should be considered when determining intake or milk yield for cows subjected to heat stress.

\section{REFERENCES}

Bitman, J., A. Lefcourt, D. L. Wood, and B. Stroud. 1982. Circadian and ultradian temperature rhythms in lactating dairy cows. J. Dairy Sci. 65(Suppl. 1):191. (Abstr.)

Cummins, K. 1992. Effect of dietary acid detergent fiber on responses to high environmental temperature. J. Dairy Sci. 75:1465-1471.

Draper, N. R., and H. S. Smith. 1981. Applied Regression Analysis. 2nd ed. Wiley, New York.

Her, E., D. Wolfenson, I. Flamenbaum, Y. Folman, M. Kaim, and A. Berman. 1988. Thermal, productive, and reproductive responses of high yielding cows exposed to short-term cooling in summer. J. Dairy Sci. 71:1085-1092.

Hetzel, D. J .S., I. L. Bennett, C. R. Holmes, R. O. Encarnacao, and M. J. Mackinon. 1988. Description and evaluation of a telemetry system for measuring body temperature in cattle. J. Agric. Sci. (Camb). 110:233-238.

Holter, J. B., J. W. West, and M. L. McGilliard. 1997. Predicting ad libitum dry matter intake and yield of Holstein cows. J. Dairy Sci. 80:2188-2199.

Holter, J. B., J. W. West, M. L. McGilliard, and A. N. Pell. 1996. Predicting ad libitum dry matter intake and yields of Jersey cows. J. Dairy Sci. 79:912-921.

Igono, M. O., G. Bjotvedt, and H. T. Sanford-Crane. 1992. Environmental profile and critical temperature effects on milk production of Holstein cows in desert climate. Int. J. Biometeorol. 36:77-87.

Igono, M. O., and H. D. Johnson. 1990. Physiologic stress index of lactating dairy cows based on diurnal pattern of rectal temperature. J. Interdiscipl. Cycle Res. 21:303-320.

Igono, M. O., H. D. Johnson, B. J. Steevens, W. A. Hainen, and M. D. Shanklin. 1988. Effect of season on milk temperature, milk growth hormone, prolactin, and somatic cell counts of lactating cattle. Int. J. Biometeorol. 32:194-200.

Igono, M. O., H. D. Johnson, B. J. Steevens, G. F. Krause, and M. D. Shanklin. 1987. Physiological, productive, and economic benefits of shade, spray, and fan system versus shade for Holstein cows during summer heat. J. Dairy Sci. 70:1069-1079.

Johnson, H. D. 1987. Bioclimate effects on growth, reproduction and milk production. Page 35 in Bioclimatology and the Adaptation of Livestock. H. D. Johnson, ed. Elsevier, Amsterdam, The Netherlands.

Johnson, H. D., A. C. Ragsdale, I. L. Berry, and M. D. Shanklin. 1963. Temperature-humidity effects including influence of acclimation in feed and water consumption of Holstein cattle. Univ. Missouri Agric. Exp. Stn. Res. Bull. 846. Columbia.

Johnson, H. D., M. Shanklin, and L. Hahn. 1988. Productive adaptability of Holstein cows to environmental heat. Univ. of Missouri Agric. Exp. Stn. Res. Bull. 1060. Columbia.

Kabuga, J. D., and K. Sarpong. 1991. Influence of weather conditions on milk production and rectal temperature of Holsteins fed two levels of concentrate. Int. J. Biometeorol. 34:226-230.

Kibler, H. H., and S. Brody. 1953. XXII. Influence of humidity on heat exchange and body temperature regulation in Jersey, Holstein, Brahman and Brown Swiss cattle. Univ. of Missouri Agric. Exp. Stn. Res. Bull. 522. Columbia.

Kibler, H. H., and S. Brody. 1950. X. Influence of temperature, $5^{\circ}$ to $95^{\circ} \mathrm{F}$, on evaporative cooling from the respiratory and exterior body surfaces in Jersey and Holstein cows. Univ. of Missouri Agric. Exp. Stn. Res. Bull. 461. Columbia.

Legates, J. E., B. R. Farthing, R. B. Casady, and M. S. Barrada. 1991. Body temperature and respiratory rate of lactating dairy cattle under field and chamber conditions. J. Dairy Sci. 74:2491-2500.

Linvill, D. E., and F. E. Pardue. 1992. Heat stress and milk production in the South Carolina Coastal Plains. J. Dairy Sci. 75:2598:2604.

Manalu, W., H. D. Johnson, R. Li, B. A. Becker, and R. J. Collier. 1991. Assessment of thermal status of somatotropin-injected lactating 
Holstein cows maintained under controlled laboratory thermoneutral hot and cold environments. J. Nutr. 121:2006-2019.

Maust, L. E., R. E. McDowell, and N. W. Hooven. 1972. Effect of summer weather on performance of Holstein cows in three stages of lactation. J. Dairy Sci. 55:1133-1139.

National Oceanic and Atmospheric Administration. 1976. Livestock hot weather stress. US Dept. Commerce, Natl. Weather Serv. Central Reg., Reg. Operations Manual Lett. C-31-76.

Purwanto, B. P., Y. Abo, R. Sakamoto, F. Furumoto, and S. Yamamoto. 1990. Diurnal patterns of heat production and heart rate under thermoneutral conditions in Holstein Friesian cows differing in milk production. J. Agric. Sci. (Camb.) 114:139-142.

Robinson, J. B., D. R. Ames, and G. A. Milliken. 1986. Heat production of cattle acclimated to cold, thermoneutrality, and heat when exposed to thermoneutrality and heat stress. J. Anim. Sci. 62:1434:1440.

SAS Institute, Inc. 1999. SAS/C OnlineDoc Release 7.00. Cary, NC. SAS Institute, Inc.

Steele, R. G. D., and J. H. Torrie. 1960. Principles and Procedures of Statistics. McGraw-Hill Book Co., New York.

West, J. W., G. M. Hill, J. M. Fernandez, P. Mandebvu, and B. G. Mullinix. 1999. Effects of dietary fiber on intake, milk yield, and digestion by lactating dairy cows during cool or hot, humid weather. J. Dairy Sci. 82:2455-2465.

West, J. W., B. G. Mullinix, J. C. Johnson, Jr., K. A. Ash, and V. N. Taylor. 1990. Effect of bovine somatotropin on dry matter intake, milk yield, and body temperature in Holstein and Jersey cows during heat stress. J. Dairy Sci. 73:2896-2906. 